\title{
Effects of the COVID-19 Pandemic on General Surgery Training in Turkey
}

\section{Türkiye'de COVID-19 Pandemisinin Genel Cerrahi Eğitimine Etkileri}

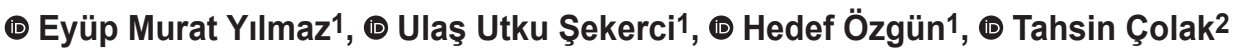 \\ ${ }^{1}$ Adnan Menderes University Faculty of Medicine, Department of General Surgery, Aydın, Turkey \\ ${ }^{2}$ Mersin University Faculty of Medicine, Department of General Surgery, Mersin, Turkey
}

\section{|IIIIIIII ABSTRACT}

Aim: The Coronavirus disease-19 (COVID-19) pandemic has affected all countries in the world and has created a serious burden on the health systems of countries. Although health systems, which have not encountered such a sudden and intense load for many years, had difficulty in responding to this need at first, measures have been taken to meet this sudden demand in a short time. This change in the health system has led to a decrease in the number of elective surgeries in particular. One of the outcomes of the COVID-19 pandemic is interrupted and insufficient surgery training. In this study, we aimed to assess the effects of COVID-19 on general surgery education in Turkey.

Method: In the study, a questionnaire consisting of 22 questions including participants' demographic information, their education level and the average number of cases in the time interval covering the same period of the previous year was used. In the study, the period between January 2019-April 2019 and January 2020-April 2020 was compared, and the operations performed during this period were compared in terms of emergency, elective, laparoscopic and open surgery.

Results: When the number of elective/emergency hernia, upper gastrointestinal-hepatobiliary and colorectal-benign anorectal operations performed primarily by the assistant under the supervision of the responsible lecturer were compared, it was found that the rates were decreased from 9.67 to $0.76,7.66$ to 1.38 and 7.48 to 2.00 , respectively, and all these changes were found to be statistically significant. The rate of emergency operations performed primarily by the lecturer decreased from $34.16 \%$ to $28.93 \%(\mathrm{p}=0.045)$, and the rate of elective surgeries performed primarily by the faculty member decreased from $61.09 \%$ to $55.93 \%$ ( $\mathrm{p}=0.045$ and $\mathrm{p}=0.411$ ).

Conclusion: There has been a significant decrease in the number of elective and emergency surgeries due to the change in the health system. We believe that changes should be made by clinics to their training programmes so that this decrease does not affect the training of surgical residents.

Keywords: COVID-19, general surgery training, laparoscopy, laparotomy

\section{|IIIIIIII| ÖZ}

Amaç: Koronavirüs hastalığı-19 (COVID-19) salgını dünyadaki tüm ülkeleri etkilemiş ve ülkelerin sağlık sistemi üzerinde ciddi bir yük oluşturmuştur. Uzun yıllardır bu kadar ani ve yoğun bir yük ile karşılaşmayan sağlık sistemleri, ilk başta bu ihtiyaca cevap vermekte zorlansa da, bu ani ihtiyacı kısa sürede karşılayacak önlemler alınmıştır. Sağlık sistemindeki bu değişiklik, özellikle elektif ameliyatların sayısının azalmasına neden olmuştur. Bu COVID-19 salgınının sonuçlarından biri, kesintiye uğrayan ve yetersiz cerrahi eğitimdir. Bu çalışmada, COVID-19'un Türkiye'deki genel cerrahi eğitimine etkilerini değerlendirmeyi amaçladık.

Yöntem: Çalışmada, katılımcıların demografik bilgileri, eğitim düzeyleri ve bir önceki yılın aynı dönemini kapsayan zaman aralığındaki ortalama olgu sayılarını içeren 22 sorudan oluşan anket kullanıldı. Çalışmada Ocak 2019-Nisan 2019 ile Ocak 2020-Nisan 2020 arasındaki dönem karşılaştırılmış ve bu dönemde yapılan vakalar acil, elektif, laparoskopik ve açık cerrahi açısından karşılaştırılmıştır.

Bulgular: Sorumlu ögretim üyesi gözetiminde asistan tarafından yapılan elektif/acil fitık (inguinal/insizyonel/umbilikal), üst gastrointestinalhepatobiliyer ve kolorektal-benign anorektal operasyon sayıları karşılaştırıldığında oranların düştügü görüldü (sırasıyla 9,67'den 0,76'ya, 7,66'dan 1,38'e ve 7,48'den 2,00'e gerilemiş ve tüm bu değişimler istatistiksel olarak anlamlı bulunmuştur). Öğretim üyesi tarafından elektif olarak yapılan acil ameliyat oranı \%34,16'dan \%28,93'e ( $\mathrm{p}=0,045)$, öğretim üyesi tarafından öncelikli olarak yapılan elektif ameliyat oranı \%61,09'dan \%55,93'e geriledi ( $\mathrm{p}=0,045$ ve $\mathrm{p}=0,411)$

Sonuç: Cerrahi eğitimin en önemli adımlarından biri, olguların öncelikle sorumlu öğretim görevlisinin gözetiminde bir asistan tarafından yapılmasıdır. Ancak bu, ameliyatın süresini uzatabilir ve olası komplikasyon riskini artırabilir. Acil olgu sayısındaki azalmaya rağmen, sorumlu

Address for Correspondence/Yazışma Adresi: Eyüp Murat Yılmaz, MD,

Adnan Menderes University Faculty of Medicine, Department of General Surgery, Aydın, Turkey

E-mail: drmyilmaz80@gmail.com ORCID ID: orcid.org/0000-0002-0808-5067

Received/Gelis Tarihi: 23.11.2020 Accepted/Kabul Tarihi: 09.12.2020

${ }^{\circ}$ Copyright 2021 by Turkish Society of Colon and Rectal Surgery

Turkish Journal of Colorectal Disease published by Galenos Publishing House. 
öğretim üyesi gözetiminde öncelikle cerrahi asistan tarafından yapılan acil olguların oranındaki artış asistan eğitimi üzerinde olumlu bir faktör olarak değerlendirilmektedir. Sağlık sistemindeki değişime bağlı olarak elektif ve acil ameliyat sayısında önemli bir düşüş yaşandı. Bu azalmanın cerrahi asistanlarının eğitimini etkilememesi için kliniklerin eğitim programlarında değişiklik yapması gerektiğini düşünüyoruz.

Anahtar Kelimeler: COVID-19, genel cerrahi eğitimi, laparoskopi, laparotomi

\section{Introduction}

With the rapid spread of the new coronavirus starting from China and spreading to the whole world in December 2019, a pandemic has posed serious problems for the economies and health systems of all countries. The first Coronavirus disease-19 (COVID-19) case in Turkey was detected in March of 2020, and the ministry of health and other government agencies have taken precautions to prevent the spread of the disease. Furthermore, it was announced that COVID-19 was no longer an epidemic limited to certain regions and was declared a pandemic in March 2020.

Although health systems, which have not encountered such a sudden and intense load for many years, had difficulty responding to this need at first, measures have been taken to meet this sudden need in a short time. Since COVID-19 primarily affects the respiratory tract, requirements for services such as hospitalisation, intensive care admission and ventilators have increased; therefore, it is certain that a need for new guidelines to help healthcare facilities meet this increased demand has emerged. ${ }^{1,2,3}$ Therefore, elective procedures have been postponed, emergency cases have been given priority and non-surgical approaches have been recommended as the first step, even in emergency cases.

This change in the health system has led to a decrease in the number of elective surgeries in particular. Many international professional organisations have advocated that elective surgery should be delayed as much as possible. ${ }^{4}$ All these changes have interrupted clinical surgery training and have led to certain new problems. The effects of COVID-19 on surgical residency programmes have only recently been realised, and studies on this subject are limited.

Considering that the COVID-19 pandemic is ongoing, and there is no specific vaccine or treatment method yet, many authors suggest that this prolonged situation will have an increasingly negative effect on resident training., ${ }^{5,6}$ Anticipating all these possible effects, clinics need to make changes in their own operations, but few centres have restructured in this direction. ${ }^{5}$ In this study, we aimed to determine the effects of COVID-19 on the health system, in particular on general surgery education.

Performing operations under the supervision of the responsible lecturer in surgical sciences resident training constitutes the basis of surgical training. As in all surgical residency programmes, general surgery has a wide range of emergency cases. Elective cases were stopped in many centres during the COVID-19 pandemic, but some hospitals were excluded from the pandemic, and elective surgeries were intended to continue in those hospitals. However, due to the health service requirement of COVID-19, which constitutes a burden on the health systems of countries, such a distinction could not be made in some countries, and the burdens brought by the COVID-19 pandemic disrupted other health services.

Elective surgeries have been postponed as much as possible since COVID-19 requires additional precautions during the surgical and anaesthesia stages to prevent disease transmission. Since COVID-19 has a much more severe course and causes higher mortality and morbidity in patient populations with susceptibility to immunosuppression, such as cancer patients, non-surgical treatments are the priority in these cases. This has also caused a decrease in the number of elective cancer surgeries.

It is inevitable that surgical training will be affected by the COVID-19 pandemic in a clinic where most of the elective cases consist of a high-risk group for COVID-19 such as elderly patients and patients with other comorbidities. Considering that training of an assistant by a responsible lecturer during surgery may prolong the duration of the operation, and this prolonged period will increase the risk of COVID-19 transmission, it can also be argued that during the pandemic, general surgery assistant training will be disrupted in both emergency and elective cases.

In this study, we aimed to assess the effects of COVID-19 on general surgery education in Turkey based on questionnaire data.

\section{Materials and Methods}

In this study, a questionnaire consisting of 22 questions, including participants' demographic information, their education level and the average number of cases in the time interval covering the same period of the previous year, was used. Questionnaires were sent to general surgery residents all over the country, and 120 residents completely filled out the form (Table 1).

The questionnaires were sent to the participants via e-mail, and the participants were asked to click on the questionnaire link and fill out the questionnaire through the online system. In the study, the period between January 2019-April 
Table 1. The questionnaire used in the study

\section{Table 1. The questionnaire used in the study}

1. Age

2. Gender

3. How long have you been a surgery resident?

4. Which hospital are you working in?

5. How many emergency cases were done in your hospital per week on average in last year (April 2019)?

6 . How many emergency cases were done in your hospital per week on average in this year (April 2020)?

7. How many elective cases were done in your hospital per week on average in last year (April 2019)?

8. How many elective cases were done in your hospital per week on average in this year (April 2020)?

9. How many elective/emergency hernia (inguinal/incisional/umbilical) surgeries did you primarily perform under the supervision of the responsible faculty member in last year (April 2019)?

10. How many elective/emergency hernia (inguinal/incisional/umbilical) surgeries did you primarily perform under the supervision of the responsible faculty member in this year (April 2020)?

11. How many elective/emergency upper gastrointestinal/hepatobiliary surgeries did you primarily perform under the supervision of the responsible faculty member in last year (April 2019)?

12. How many elective/emergency upper gastrointestinal/hepatobiliary surgeries did you primarily perform under the supervision of the responsible faculty member in this year (April 2020)?

13. How many elective/emergency colorectal, benign anorectal surgeries did you primarily perform under the supervision of the responsible faculty member in last year (April 2019)?

14. How many elective/emergency colorectal, benign anorectal surgeries did you primarily perform under the supervision of the responsible faculty member in this year (April 2020)?

15. As a surgical assistant, in which emergency case did you frequently encounter during the pandemic process and feel better about making a primarily?

16. What percentage of hernia (inguinal/umbilical/incisional) cases did you do laparoscopically in last year (2019)?

17. What percentage of hernia (inguinal/umbilical/incisional) cases did you do laparoscopically in this year (2020)?
- 20-29

- 30-39

- 40-49

- $>50$

- Male

- Female

$-<1$ year

- 2 years

- 3 years

- 4 years

- 5 years or more

- Public university hospital

- Research and training hospital

- Foundation/private university hospital 
Table 1. continued

18. What percentage of upper gastrointestinal, hepatobiliary cases did you do laparoscopically in last year (2019)?

19. What percentage of upper gastrointestinal, hepatobiliary cases did you do laparoscopically in this year (2020)?

20. What percentage of colorectal cases did you do laparoscopically in last year (2019)?

21. What percentage of colorectal cases did you do laparoscopically in this year (2020)?

22. What is the reason affecting your laparoscopy or laparotomy choice?

- Laparoscopic surgeries are safer in terms of transmission

- Open operations are safer in terms of transmission

- Laparoscopy needs shorter operation duration

- Laparostomy needs shorter operation duration

- I am more experienced in laparoscopic operations

- I am more experienced in open operations

- Due to hospital policy

- Due to defence of the staff

- Due to hospital facilities

- The choice of lecturers

- Due to defence of the anaesthesia

23. How many of the emergency surgeries were performed primarily by the lecturer in last year (2019)?

24. How many of the emergency surgeries were performed primarily by the lecturer in this year (2020)?

25. How many of the elective surgeries were performed primarily by the lecturer in last year (2019)?

26. How many of the elective surgeries were performed primarily by the lecturer in this year (2020)?

2019 and January 2020-April 2020 was compared, and the operations performed during this period were compared in terms of emergency, elective, laparoscopic and open surgery. In addition, the rates of inguinal, incisional and umbilical hernia; upper gastrointestinal-hepatobiliary surgery and colorectal and benign anorectal surgeries performed in the same period were compared in terms of whether the surgery was performed mainly by the lecturer or the resident.

\section{Statistical Analysis}

SPSS Statistics for Windows, Version 20.0. (Armonk, NY: IBM Corp.) was used to evaluate the data. Variables were expressed as mean \pm standard deviation, percentage and frequency values. In addition, the normality assumption, one of the prerequisites of parametric tests, was tested with the Shapiro-Wilk test. For evaluation of differences between two groups, when the preconditions of parametric tests were met, the matching t-test was used; otherwise, the Wilcoxon test was applied. The statistical significance level was accepted as $\mathrm{p}<0.05$ and $\mathrm{p}<0.01$.

\section{Results}

A total of 120 general surgery residents participated in the study. Of them, 62 residents ( $51.7 \%$ ) were between the ages of 20 and 29, 56 (46.7\%) between 30 and 39 and $2(1.7 \%)$ between 40 and 49 . In all, 104 (86.7\%) of the respondents were male, while the remaining 16 (13.3\%) were female. In terms of the surgical experience, 16 residents (13.3\%) had less than 1 year, 10 residents (8.3\%) had 1 year, 26 residents (21.7\%) had 2 years, 24 assistants (20\%) had 3 years, 26 assistants $(21.7 \%)$ had 4 years and 18 residents (15\%) had 5 years or more. Eighty of the participants $(66.7 \%)$ were working in a public university hospital, $36(30 \%)$ in training and research hospitals and the remaining 4 (3.3\%) in a foundation or private university hospital (Table 2).

When the admissions were analysed, it was observed that $37.9 \%$ of the emergency cases were operated due to appendicitis, $23.3 \%$ due to ileus, $8.6 \%$ due to trauma, $12.9 \%$ due to mesenteric ischaemia, $15.5 \%$ due to upper gastrointestinal perforation and approximately $1.7 \%$ 
due to other surgical emergencies. When the factors that affect surgeons' choice of laparoscopy or laparotomy in emergency cases were examined, it was found that $3.1 \%$ of the participants found laparoscopic surgeries safer in terms of contamination, $23.9 \%$ found open operations safer in terms of contamination, $18.9 \%$ asserted that surgery times were shorter in open operations, $1.3 \%$ thought that they were more skilful in laparoscopic operations, $6.9 \%$ thought that they were more skilful in open operations, $0.6 \%$ stated that laparoscopic surgeries take less time, $13.2 \%$ stated that they make their choices due to hospital policy, $6.9 \%$ due to defence of the hospital staff and 5\% due to the hospital's facilities, $10.7 \%$ preferred laparoscopy or laparotomy due to the preference of the lecturer and $9.4 \%$ due to the defence of the anaesthesia (Table 3).

When the period between January and April 2019 was examined, the weekly average number of emergency cases was calculated as 28.34 , while the weekly average number of elective cases in the same period was 69.27. When the cases under the supervision of a responsible lecturer were examined, it was seen that the average number of elective/emergency inguinal, incisional or umbilical hernia operations performed in the same period of 2019 was 9.67 , the average number of upper gastrointestinal/hepatobiliary cases was 7.66 and the average number of colorectal and benign anorectal cases was 7.48 . When the period between

Table 2. Demographic characteristics of the participants

\begin{tabular}{lll} 
Age (years) & $\%$ & $\mathbf{n}$ \\
\hline $20-29$ & 51.7 & 62 \\
$30-39$ & 46.7 & 56 \\
$40-49$ & 1.7 & 2 \\
Gender & & \\
Male & 86.7 & 104 \\
Female & 13.3 & 16 \\
Experience (years) & & \\
$<1$ & 13.3 & 16 \\
1 & 8.3 & 10 \\
2 & 21.7 & 26 \\
3 & 20.0 & 24 \\
4 & 21.7 & 26 \\
5 or more & 15.0 & 18 \\
Hospital type & & \\
Public university hospital & 66.7 & 80 \\
Training and research hospital & 30.0 & 36 \\
Foundation or private university hospital & 3.3 & 4 \\
\hline
\end{tabular}

January and April 2020 was examined, the weekly average number of emergency cases was calculated as 16.07 , while the weekly average number of elective cases in the same period was 13.22. When cases under the supervision of a responsible lecturer were examined, it was seen that the average number of elective/emergency inguinal, incisional or umbilical hernia surgeries performed in the same period of 2020 was 0.76 , the average number of upper gastrointestinal/ hepatobiliary cases was 1.38 and the average number of colorectal and benign anorectal cases was 2.0.

When the distribution of surgeries performed between January and April 2019 in terms of laparoscopy or laparotomy was examined, $23.07 \%$ of elective/emergency inguinal, incisional or umbilical hernia surgeries, $40.70 \%$ of upper gastrointestinal/hepatobiliary surgeries, and $26.60 \%$ of colorectal surgeries were performed laparoscopically. In the same period, it was observed that $34.16 \%$ of the emergency surgeries were primarily carried out by the responsible lecturer, while this rate was $61.09 \%$ for cases elective cases.

When the distribution of surgeries performed between January and April of 2020, were compared in terms of laparoscopy or laparotomy, $4.55 \%$ of elective/emergency inguinal, incisional or umbilical hernia surgeries, $5.91 \%$ of upper gastrointestinal/hepatobiliary surgeries, and $4.82 \%$ of colorectal surgeries were performed laparoscopically. In the same period, it was observed that $28.93 \%$ of emergency surgeries were primarily carried out by the responsible faculty member, and this rate was $55.93 \%$ for elective cases. When the periods between January-April 2019 and JanuaryApril 2020 were compared, it was determined that the weekly number of emergency cases decreased from 28.34 to 16.07

Table 3. Factors that affect the choice of surgery type

$\begin{array}{lll}\text { Reason for laparoscopy or laparotomy choice } & \% & \mathbf{n} \\ \begin{array}{l}\text { Laparoscopy is safer in terms of disease } \\ \text { transmission }\end{array} & 3.1 \% & 4 \\ \begin{array}{l}\text { Laparotomy is safer in terms of disease } \\ \text { transmission }\end{array} & 23.9 \% & 29 \\ \begin{array}{ll}\text { Laparotomy takes shorter time } \\ \text { I am more experienced in laparoscopic surgeries }\end{array} & 1.3 \% & 2 \\ \text { I am more experienced in open surgeries } & 6.9 \% & 8 \\ \text { Laparoscopy takes shorter time } & 0.6 \% & 1 \\ \text { Due to hospital policy } & 13.2 \% & 16 \\ \text { Due to defence of hospital staff } & 6.9 \% & 8 \\ \text { Due to hospital's facilities } & 5.0 \% & 6 \\ \text { Choice of the lecturer } & 10.7 \% & 13 \\ \text { Due to defence of the anaesthetist } & 9.4 \% & 11\end{array}$


on average and there is a statistically significant difference $(\mathrm{p}=0.002)$. When the elective cases were compared, it was seen that the weekly average number of cases decreased from 69.27 to 13.22, and there was a statistically significant difference $(\mathrm{p}=0.001)$. When the number of elective/ emergency hernia (inguinal/incisional/umbilical), upper gastrointestinal-hepatobiliary and colorectal-benign anorectal operations performed primarily by the assistant under the supervision of the responsible lecturer were compared, it was found that the rates were decreased from 9.67 to $0.76,7.66$ to 1.38 and 7.48 to 2.00 , respectively, and all these changes were found to be statistically significant ( $\mathrm{p}=0.001,0.001,0.001$, respectively) (Table 4).

While $23.07 \%$ of hernia (inguinal/incisional/umbilical) operations were performed laparoscopically in 2019, this rate decreased to $4.55 \%$ in the same period of 2020 $(\mathrm{p}=0.001)$. When the same comparison was made for upper gastrointestinal-hepatobiliary and colorectal surgeries, it was observed that these rates decreased from $40.71 \%$ to $5.91 \%$ and from $27.60 \%$ to $4.82 \%$, respectively ( $\mathrm{p}=0.001, \mathrm{p}=0.001$ ). When the periods of 2019 and 2020 are compared, it is seen that the rate of emergency operations performed primarily by the lecturer decreased from $34.16 \%$ to $28.93 \%$ ( $\mathrm{p}=0.045$ ), and the rate of elective surgeries performed primarily by the faculty member decreased from $61.09 \%$ to $55.93 \%$ ( $\mathrm{p}=0.045$ and $\mathrm{p}=0.411$ ) (Table 5).

\section{Discussion}

Although the issue of which method (laparoscopy or laparotomy) is safer in terms of transmission risk in infected

Table 4. Comparison of emergency and elective cases performed before and after the COVID-19 pandemic

$\begin{array}{llll} & 2019 & 2020 & \mathrm{p} \\ \begin{array}{l}\text { How many emergency cases were done } \\ \text { in your hospital per week on average? }\end{array} & 28.34 & 16.07 & 0.002 \\ \begin{array}{l}\text { How many elective cases were on } \\ \text { average per week in your hospital? }\end{array} & 69.27 & 13.22 & 0.001 \\ \begin{array}{l}\text { On average, how many elective/ } \\ \text { emergency hernia (inguinal/incisional/ } \\ \text { umbilical) surgeries have you } \\ \text { performed under the supervision of } \\ \text { the responsible lecturer? }\end{array} & 9.67 & 0.76 & 0.001 \\ \begin{array}{l}\text { How many elective/emergency upper } \\ \text { GIS-hepatobiliary surgeries have } \\ \text { you performed primarily under the } \\ \text { supervision of the responsible lecturer? }\end{array} & 7.66 & 1.38 & 0.001 \\ \begin{array}{l}\text { On average, how many elective/ } \\ \text { emergency colorectal-benign anorectal } \\ \text { operations have you performed under } \\ \text { the supervision of the responsible } \\ \text { lecturer? }\end{array} & 7.48 & 2.00 & 0.001 \\ \end{array}$

COVID-19: Coronavirus disease-19, GIS: Gastrointestinal system patients is controversial, the general opinion is that the open method is safer. ${ }^{7}$ Although there is no evidence that COVID-19 causes transmission by vaporisation during the operation, it should be acted on considering the possibility of transmission as it carries a potential risk. ${ }^{8}$ In our study, when the rates of laparoscopy were compared, it was found that there was a statistically significant decrease in the laparoscopy rates in all surgeries performed. Considering that the risk of contamination with laparoscopy is higher, a decrease in laparoscopy rates is predictable. Considering that this situation may cause a deficiency in laparoscopic training of residents, it may be recommended to exclude the diagnosis of COVID-19 by performing preoperative polymerase chain reaction test in elective cases and to operate on COVID-19-negative patients laparoscopically as much as possible. In this way, the deficiency in laparoscopic training can be prevented to some extent.

One of the most important steps of surgical training is that operations are performed primarily by an assistant under the supervision of the responsible lecturer. However, this can prolong the duration of the surgery and increase the risk of possible complications. ${ }^{9,10}$ All these factors also cause an increase in the risk of COVID-19 transmission. In our study, during the pandemic period, in which $34.6 \%$ of emergency surgeries were primarily performed by the lecturer in 2019 , it was observed that this rate decreased to $28.3 \%$ in 2020 , and a statistically low significant difference was observed. Despite the decrease in the number of emergency cases, the increase in the rate of emergency surgeries primarily performed by the surgical assistant under the supervision of the responsible lecturer is considered as a positive factor in resident training. Likewise, it was observed that the rate of elective surgeries performed primarily by residents increased during the pandemic, but this change was not statistically significant $(61.09 \%$ vs $55.93 \%, p=0.411)$.

Table 5. Comparison surgery types before and after the COVID-19 pandemic

$\begin{array}{lccc} & 2019 & 2020 & \mathrm{p} \\ \begin{array}{l}\text { What percentage of hernia (inguinal/ } \\ \begin{array}{l}\text { umbilical/incisional) cases have you } \\ \text { performed laparoscopically? }\end{array}\end{array} & 23.07 & 4.55 & 0.001 \\ \begin{array}{l}\text { What percentage of upper GIS- } \\ \text { hepatobiliary cases have you performed } \\ \text { laparoscopically? }\end{array} & 40.71 & 5.91 & 0.001 \\ \begin{array}{l}\text { What percentage of colorectal cases have } \\ \text { you done laparoscopically? }\end{array} & 27.60 & 4.82 & 0.001 \\ \begin{array}{l}\text { How much of the emergency surgeries } \\ \text { primarily performed by lecturers? }\end{array} & 34.16 & 28.93 & 0.045 \\ \begin{array}{l}\text { How many of the elective surgeries } \\ \text { primarily performed by lecturers? }\end{array} & 61.09 & 55.93 & 0.411\end{array}$

COVID-19: Coronavirus disease-19, GIS: Gastrointestinal system 
When the elective cases before and after the pandemic were compared, considering that the weekly average number of cases decreased from 69.27 to 13.22 and that there was a statistically significant difference between these two periods $(\mathrm{p}=0.001)$, there was also a significant difference in the number of elective surgeries performed primarily by the surgery resident. Making a primary case under the supervision of responsible lecturer is one of the most important stages of surgical training, and the interruption of this step may cause major deficiencies in surgical training. Since a protective vaccine or a specific therapeutic drug against COVID-19 cannot be developed today and it is not certain how long this situation will continue, it is thought that the rate of operations performed primarily by the surgical resident should increase in order not to interrupt surgical training. ${ }^{11}$ We believe that this deficiency can be reduced to some extent by increasing the rate of surgeries primarily performed by the surgery resident insofar as possible according to the experience of the resident.

\section{Conclusion}

The COVID-19 pandemic has affected all countries around the world and has created a serious burden on the health systems of countries. There has been a significant decrease in the number of elective and emergency surgeries due to changes in such health systems. It is our opinion that changes should be made by clinics in their training programmes so that this decrease does not affect the training of surgical residents.

\section{Ethics}

Ethics Committee Approval: Approval was obtained from Aydin Adnan Menderes University Local Ethics Committee for the study.

Informed Consent: Since the study is a questionnaire form, there is no patient consent form.

Peer-review: Externally and internally peer reviewed.

\section{Authorship Contributions}

Surgical and Medical Practices: E.M.Y., U.U.Ş., Concept: E.M.Y., H.Ö., Design: T.Ç., E.M.Y., Data Collection or Processing: U.U.Ç., H.Ö., Analysis or Interpretation: T.Ç., H.Ö., Literature Search: E.M.Y., U.U.Ş., Writing: E.M.Y.

Conflict of Interest: No conflict of interest was declared by the authors.

Financial Disclosure: The authors declared that this study received no financial support.

\section{References}

1. Ross SW, Lauer CW, Miles WS, Green JM, Christmas AB, May AK, Matthews $\mathrm{BD}$. Maximizing the calm before the storm: tiered surgical response plan for novel coronavirus (COVID-19). J Am Coll Surg 2020;230:1080-1091.e3

2. Kamer E, Çolak T. COVID-19 ile enfekte bir hastanın ameliyat olması gerektiğinde yapılması gerekenler: ameliyat öncesi, peri-ameliyatı ve ameliyat sonrası kılavuzu. Turk J Colorectal Dis 2020;30:1-8.

3. Kamer E, Çolak T. Kontrollü COVID-19 pandemisinde genel cerrahi seçmeli cerrahiye dönüş stratejisi. Turk J Colorectal Dis 2020;30:86-93.

4. Recommendations for management of elective surgical procedures. American College of Surgeons, 2020. Available from: https://www.facs.org/ covid-19/clinical-guidance/elective-surgery

5. White EM, Shaughnessy MP, Esposito AC, Slade MD, Korah M, Yoo PS. Surgical education in the time of COVID: Understanding the early response of surgical training programs to the novel coronavirus pandemic. J Surg Edu 2020, 2020 Jul 25 [Online ahead of print]

6. Alvin MD, George E, Deng F, Warhadpande S, Lee SI. The impact of COVID-19 on radiology trainees [published online ahead of print] Radiology doi: 10.1148/radiol.2020201222

7. Dexter F, Parra MC, Brown JR, Loftus RW. Perioperative COVID-19 defense: an evidence-based approach for optimization of infection control and operating room management. Anesth Analg 2020;131:37-42.

8. De Simone B, Chouillard E, Di Saverio S, Pagani L, Sartelli M, Biffl WL, Coccolini F, Pieri A, Khan M, Borzellino G, Campanile FC, Ansaloni L, Catena F. Emergency surgery during the COVID-19 pandemic: what you need to know for practice. Ann R Coll 2020;102:323-332.

9. Vigneswaran Y, Prachand VN, Posner MC, Matthews JB, Hussain M. What is the appropriate use of laparoscopy over open procedures in the current COVID-19 Climate?. J Gastrointest Surg 2020;24:1686-1691.

10. Nassar AH, Zern NK, McIntyre LK, Lynge D, Smith CA, Petersen RP, Horvath KD, Wood, DE. Emergency restructuring of a general surgery residency program during the coronavirus disease 2019 pandemic: The University of Washington Experience. JAMA Surg 2020;155:624-627.

11. Bryan DS, Benjamin AJ, Schneider AB, Milner R, Matthews JB, Roggin KK. Nimble, together: a training program's response to the COVID-19 Pandemic. Ann Surg 2020;272:el42-el43. 


\title{
Pelvic Exenteration for Recurrent Rectal Cancer: a Single Institution Experience
}

\section{Rekürren Rektal Kanserlerde Pelvik Ekzantrasyon: Tek Merkez Deneyimi}

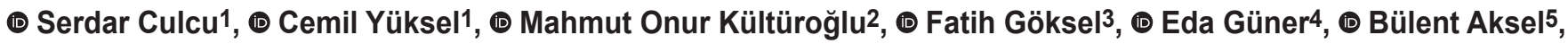 \\ (1) Lütfi Doğan1 \\ 1 University of Health Sciences Turkey, Dr. Abdurrahman Yurtaslan Training and Research Hospital, Clinic of Surgical Oncology, Ankara, Turkey \\ 2Erciyes University Faculty of Medicine, Department of General Surgical, Kayseri, Turkey \\ 3University of Health Sciences Turkey, Dr. Abdurrahman Yurtaslan Training and Research Hospital, Clinic of Radiation Oncology, Ankara, Turkey \\ 4University of Health Sciences Turkey, Dr. Abdurrahman Yurtaslan Training and Research Hospital, Clinic of General Surgery, Ankara, Turkey \\ 5University of Health Sciences Turkey, Ankara Oncology Health Practice and Research Center, Clinic General Surgical, Ankara, Turkey
}

\section{IIIIIIII| ABSTRACT}

Aim: Rectal cancer is an important cause of cancer-related deaths worldwide (1-2). Although rectal cancers can be diagnosed earlier nowadays due to the development of screening programmes, $18 \%$ of patients have a locally advanced stage at the time of diagnosis (3). Despite the improvements in total mesorectal excision and oncological treatments, the locoregional recurrence rates vary between 6-10\% in rectal cancer patients (4-5).

Method: The data of patients who underwent pelvic exenteration for recurrent rectal cancer in our clinic between January 2015 and December 2019 were retrospectively analysed.

Results: It was found that the patients with lymphovascular invasion (LVI) and perineural invasion (PNI) showed statistically poor survival rates $(\mathrm{p}=0.038 / 0.022)$. Two of the patients had a positive surgical margin and two others had a positive radial margin. There was no statistically significant difference between surgical margin positivity and prognosis ( $>>0.05)$. The mean number of metastatic lymph nodes was $4.0(0-12)$, and the total number of lymph nodes was 12.35 (2-27). There was no statistically significant difference between patients with lymph node metastasis in terms of survival ( $\mathrm{p}=0.079$ ). Seven of the patients $(41.1 \%)$ received systemic treatment before the surgery. It was statistically determined that the patients who received this treatment showed better survival rates $(\mathrm{p}=0.045)$.

Conclusion: It was found that pelvic exenteration had a positive effect on survival and local recurrence in recurrent rectal cancer, and that neoadjuvant therapy increased survival rates.

Keywords: Complication, pelvic exenteration, rectal cancer, recurrence, survival

\section{|||||||||| ÖZ}

Amaç: Rektal kanser tüm dünyada kansere bağlı ölümlerin önemli bir nedenidir (1-2). Günümüzde gelişen tarama programları ile birlikte rektal kanserlere daha erken tanı konulabilse de tanı anında hastaların \%18'i lokal ileri evrededir (3). Total mezorektal eksizyon ve onkolojik tedavilerdeki gelişmelere rağmen rektum kanserli hastalarada lokorejyonel rekurrens oranları \%6-10 arasında değişmektedir (4-5).

Yöntem: Kliniğimizde Ocak 2015-Aralık 2019 tarihleri arasında nüks rektum kanseri nedeniyle pelvik ekzantrasyon yapılan hastaların verileri retrospektif olarak inceledi.

Bulgular: Patoloji raporları incelendiğinde hastaların 10'unda (\%58,8) lenfovasküler invazyon, 10'unda (\%58,8) perinöral invazyon vardı. lenfovasküler invazyon ve perinöral invazyon olan hastaların istatistiksel olarak kötü sağkalım gösterdikleri saptanmıştır ( $\mathrm{p}=0,038 / 0,022)$. Hastaların 2'sinde cerrahi sınır pozitif gelmiş olup, 2'si de radyal sınır pozitifliğiydi. Cerrahi sınır pozitifliği ile prognoz arasında istatistiksel olarak anlamlı fark yoktu $(p>0,05)$. Metastatik lenf nodu sayısı ortalama 4,0 (0-12), toplam lenf nodu sayısı ortalama 12,35 (2-27) olarak bulunmuştur. Lenf nodu metastazı olan hastalarda sağkalım açısından istatistiksel olarak fark bulunmamıştır ( $\mathrm{p}=0,079$ ). Hastaların 7'si (\%41,1) operasyon öncesi sistemik tedavi almıştır. Sistemik tedavi alan hastaların daha iyi sağkalım gösterdiği istatistiksel olarak saptanmıştır $(\mathrm{p}=0,045)$.

Sonuç: Nüks rektum kanserinde pelvik ekzantrasyon ve neoadjuvan tedavinin sağ kalımı artırdığı lokal nüksü azalttığı gözlenmiştir.

Anahtar Kelimeler: Komplikasyon, pelvik ekzantrasyon, rektum kanser, nüks, sağkalım

Address for Correspondence/Yazışma Adresi: Serdar Culcu, MD,

University of Health Sciences Turkey, Dr. Abdurrahman Yurtaslan Training and Research Hospital, Clinic of Surgical Oncology, Ankara, Turkey

E-mail: serdarculcu@gmail.com ORCID ID: orcid.org/0000-0002-1136-1771

Received/Geliş Tarihi: 07.08.2020 Accepted/Kabul Tarihi: 30.09.2020

${ }^{\odot}$ Copyright 2021 by Turkish Society of Colon and Rectal Surgery

Turkish Journal of Colorectal Disease published by Galenos Publishing House. 


\section{Introduction}

Rectal cancer is an important cause of cancer-related deaths worldwide. ${ }^{1,2}$ Although rectal cancers can be diagnosed earlier nowadays due to the development of screening programmes, $18 \%$ of patients have a locally advanced stage at the time of diagnosis. ${ }^{3}$ Despite the improvements in total mesorectal excision and oncological treatments, the locoregional recurrence rates vary between $6 \%-10 \%$ in rectal cancer patients. ${ }^{4,5}$ Invasion to the genitourinary organs occurs in some patients with pelvic recurrence. ${ }^{6,7}$ Pelvic recurrences may present with symptoms such as pain, tenesmus, dysuria and fistula that cannot be controlled by treatment. ${ }^{8}$ The procedure of removing all tumour tissues in order to achieve negative surgical margins in the pelvis is called pelvic exenteration, which significantly contributes to survival in well-selected patient groups with a multidisciplinary approach.

This study aimed to present the outcomes of our patients who underwent pelvic exenteration for locoregional recurrence and to determine the prognostic factors.

\section{Materials and Methods}

Data of patients who underwent pelvic exenteration for recurrent rectal cancer in our clinic between January 2015 and December 2019 were retrospectively analysed. Patients with a pelvic recurrence who developed systemic metastasis were not operated. The site of local recurrence and presence of a distant metastasis in all patients were evaluated by magnetic resonance imaging (MRI) and computed tomography (CT). Preoperative colonoscopy was performed on the patients to locate the tumour site, and cystoscopy was performed on patients with suspected bladder invasion. A total of 17 patients who met these criteria were included in the study. The patients' surgery types and pathology reports, demographic features, length of hospital stay, reasons for re-admission, postoperative complications, postoperative mortality, total and disease-free survival were examined. The radiological examinations (chest X-ray, CT, ultrasonography, endoultrasonography, MRI, positron emission tomography) were reviewed by retrospectively scanning the patients' data. The $8^{\text {th }}$ edition of the TNM classification was used for staging. Ethics committee approval was obtained from our institute. All patients were operated by the same surgical team. Informed consent was obtained from the patients in the preoperative period. The patients underwent bowel cleansing using laxatives and enemas a day before the surgery, and a single-dose prophylactic antibiotic (cefazolin 2 gr) was administered preoperatively. The patients underwent total pelvic exenteration (TPE). TPE is defined as the removal of the genitourinary and reproductive organs including the rectum, distal colon, distal ureters and the lymph nodes draining these, as well as the pelvic peritoneum, and this procedure can be performed in combination with sacrectomy. Afterwards, reconstructions such as lower anastomoses instead of permanent ileostomy, new vagina due to sexual dysfunction, urinary diversion (new bladder or supravesical urinary diversion) and flapgrafts to close the pelvic floor defects can be performed in order to increase the quality of life.

\section{Statistical Analysis}

Data analysis was done using SPSS 11.5 software. For descriptive statistics, quantitative variables were presented as mean \pm standard deviation and median (minimummaximum), and qualitative variables were presented as number of patients (percentage). A survival analysis was performed using the Kaplan-Meier method through qualitative and quantitative variables and the log-rank test was used to determine significant differences between the groups. The level of statistical significance was set at 0.05 .

\section{Results}

Of the patients, 9 (52.9\%) were females and $8(47.1 \%)$ were males. The mean age of the patients was $53.4 \pm 10.1$ years. TPE was performed on all the patients, of whom, 6 (35.3\%) had lower, 7 (41.2\%) had middle, and 4 (23.5\%) had upper rectum localisation, and there was no significant correlation between the survival of the patients and tumour localisation $(p>0.05)$. We had performed a low anterior resection for all patient for the initial surgery and all surgical margins were clear. Of the patients, 12 (70.5\%) had taken neoadjuvant chemoradiotherapy before the initial surgery. When classified according to T-stage, three patients were T2 (11.7\%), five patients were T3 (29.4\%), three patients were $\mathrm{T} 4 \mathrm{a}(11.7 \%)$ and six patients were $\mathrm{T} 4 \mathrm{~b}(35.2 \%)$. It was observed that survival decreased as the T-stage increased $(\mathrm{p}<0.001)$. $\mathrm{N}$ was positive in $11(64.7 \%)$ and $\mathrm{N}$ was negative in 6 (35.3\%) patients. Mortality was found to be high in patients with $\mathrm{N}$ positive results and was statistically significant $(\mathrm{p}<0.05)$. There was no statistical significance in terms of overall survival, disease-free survival and deficit conversion $(p>0.05)$. The mean follow-up duration was 16 months (1-50 months), and considering overall survival, 8 (47.1\%) of 17 patients survived, while 9 (52.9\%) died. The mean survival time was 23.8 months. Three of the patients (11.7\%) developed recurrence, and all recurrences occurred in the pelvic region as a local recurrence. The mean length of hospital stay was $18.1 \pm 11.5$ days. The patient characteristics are shown in Table 1.

The surgical indication was vaginal invasion in 5 (29.4\%) patients, bladder invasion in 11 (64.7\%) patients and uterine 
invasion in 1 (5.8\%) patient. The mean operative time was $200.8 \pm 9.2 \mathrm{~min}$. Of the patients, five developed an infection, one developed an ileal conduit leak and one developed postoperative early bleeding. There was no statistically significant correlation between complication development and survival in the patients $(p>0.05)$. Only the patient who

Table 1. Patient characteristics

\begin{tabular}{|c|c|c|}
\hline Age & \multicolumn{2}{|l|}{$53.47 \pm 10.16$} \\
\hline $\begin{array}{l}\text { Total number of lymph } \\
\text { nodes removed }\end{array}$ & \multicolumn{2}{|l|}{$12.35 \pm 1.77$} \\
\hline $\begin{array}{l}\text { Number of metastatic } \\
\text { lymph nodes }\end{array}$ & \multicolumn{2}{|l|}{$4.00 \pm 0.94$} \\
\hline Survival time (months) & \multicolumn{2}{|l|}{$23.83 \pm 5.07$} \\
\hline \multirow{2}{*}{ Lymphovascular invasion } & Yes & $10(58.8)$ \\
\hline & No & $7(41.2)$ \\
\hline \multirow{2}{*}{ Perineural invasion } & Yes & $10(58.8)$ \\
\hline & No & $7(41.2)$ \\
\hline \multirow{2}{*}{ Recurrence } & Yes & $3(17.6)$ \\
\hline & No & $14(82.4)$ \\
\hline Operative time (min) & \multicolumn{2}{|l|}{$200.88 \pm 9.27$} \\
\hline \multirow{2}{*}{$\begin{array}{l}\text { Preoperative systemic } \\
\text { treatment }\end{array}$} & Yes & $7(41.2)$ \\
\hline & No & $10(58.8)$ \\
\hline $\begin{array}{l}\text { Length of hospital stay } \\
\text { (days) }\end{array}$ & \multicolumn{2}{|l|}{$18.12 \pm 2.80$} \\
\hline \multirow{3}{*}{ Reason for re-admission } & Infection & $7(63.8)$ \\
\hline & $\mathrm{ARF}$ & $1(9)$ \\
\hline & $\begin{array}{l}\text { Deterioration of } \\
\text { general condition }\end{array}$ & $3(27.2)$ \\
\hline
\end{tabular}

Min: Minimum, ARF: Acute rheumatic fever developed an ileal conduit leak required reoperation, while the other patients were treated conservatively. Seven patients were readmitted to the hospital for infection, one patient for acute renal failure and three patients for deterioration of the general condition, and the causes of infection were pyuria ${ }^{2}$, intra-abdominal collection ${ }^{4}$ and wound infection. ${ }^{1}$

When the pathology reports were examined, 10 (58.8\%) of the patients had lymphovascular invasion (LVI) and 10 (58.8\%) had perineural invasion (PNI). It was found that the patients with LVI and PNI showed statistically poor survival rates $(\mathrm{p}=0.038 / 0.022)$. Of the patients, two had a positive surgical margin and two had a positive radial margin. There was no statistically significant difference between surgical margin positivity and prognosis $(p>0.05)$. The mean number of metastatic lymph nodes was 4.0 (0-12), and the total number of lymph nodes was 12.35 (2-27). There was no statistically significant difference between patients with lymph node metastasis in terms of survival ( $\mathrm{p}=0.079)$.

Seven of the patients $(41.1 \%)$ received chemoradiotherapy before pelvic exenteration. In accordance with the multidisciplinary team decision, 10 (58.9\%) of the patient did not receive chemoradiotherapy before pelvic exenteration. It was statistically determined that the patients who received this treatment showed better survival rates $(\mathrm{p}=0.045)$.

According to the Kaplan-Meier analysis, the one-year and 2 -year survival rate was $74 \%$ and $26 \%$, respectively. It was statistically shown that the patients who had 12 months or less between the initial operation and pelvic recurrence had worse survival rates than those who had more than 12 months between the initial operation and pelvic recurrence $(\mathrm{p}=0.001)$. Table 2 presents the univariate analysis results that were suggested to affect survival, and the probability of the 1- and 2-year survivals related to these results.

Table 2. Survival analyses

\begin{tabular}{|c|c|c|c|c|c|}
\hline & & 1 year (\%) & 2 years $(\%)$ & Survival time & $\mathrm{p}$ \\
\hline Overall & & 74.0 & 26.9 & $23.83 \pm 5.07$ & - \\
\hline \multirow{2}{*}{ Neoadjuvant therapy } & No & 63.5 & 19.5 & $14.06 \pm 2.77$ & \multirow{2}{*}{0.045} \\
\hline & Yes & 85.7 & 64.3 & $36.64 \pm 7.74$ & \\
\hline \multirow{2}{*}{ LVI } & No & 80.0 & 80.0 & $41.20 \pm 7.87$ & \multirow{2}{*}{0.038} \\
\hline & Yes & 70.0 & 16.7 & $14.70 \pm 2.55$ & \\
\hline \multirow{2}{*}{ PNI } & No & 83.3 & 83.3 & $42.66 \pm 6.69$ & \multirow{2}{*}{0.022} \\
\hline & Yes & 57.1 & 15.2 & $14.32 \pm 2.56$ & \\
\hline \multirow{2}{*}{ Metastatic lymph node } & No & 75.0 & 50.0 & $39.00 \pm 9.52$ & \multirow{2}{*}{0.079} \\
\hline & Yes & 72.7 & 13.6 & $17.18 \pm 3.15$ & \\
\hline \multirow{2}{*}{ Sex } & Female & 55.6 & 27.8 & $21.52 \pm 6.52$ & \multirow{2}{*}{0.507} \\
\hline & Male & 27.8 & 0 & $20.66 \pm 2.37$ & \\
\hline
\end{tabular}

PNI: Perineural invasion, LVI: Lymphovascular invasion 


\section{Discussion}

Pelvic exenteration was first described in 1948 in Brunschwig pelvic malignancies as the en bloc resection of pelvic organs. ${ }^{9}$ Although the mortality rates have been shown to be $20-30 \%$ for many years, this rate has dropped to $<10 \%$ due to the improvements in the surgical technique, intensive care and anaesthesiology. ${ }^{10,11,12,13}$

Rectal cancer surgery is particularly challenging in lower rectal tumours and in patients having a narrow pelvis. Despite all the advances in the surgical technique, the locoregional recurrence rates in colorectal cancer vary between $6 \%-10 \%{ }^{4,5}$ The vast majority of recurrences occur within the first three years after surgery, and when these patients are left untreated, the prognosis varies between 6-8 months. ${ }^{14}$ Patients whose tumour is limited to the pelvis and who do not have distant metastasis are eligible for pelvic exenteration. However, pelvic exenteration can be performed in combination with metastasectomy in a group of patients with resectable distant liver and lung metastases. ${ }^{7,15,16}$ Resectability should be determined by preoperative imaging, including CT, MRI and positron emission tomography. Siatic nerve invasion, external iliac artery invasion, paraaortic lymph node involvement and lymphoedema as a finding of venous or lymphatic infiltration in the lower extremity are considered contraindications for pelvic exenteration. ${ }^{17}$ TPE is defined as the removal of the genitourinary and reproductive organs including the rectum, distal colon, distal ureters and the lymph nodes draining them as well as the pelvic peritoneum and can be performed in combination with sacrectomy. Anterior pelvic exenteration is the resection of the reproductive organs, upper rectum and bladder by preserving the lower part of the rectum. Posterior pelvic exenteration is defined as the resection of the rectum and reproductive organs by preserving the bladder. In our study, all of the patients underwent TPE.

Despite the high mortality and morbidity rates, pelvic exenteration is associated with increased survival in recurrent rectum tumours. In their systemic review, Heriot et al. ${ }^{18}$ showed that pelvic exenteration increased survival with an acceptable morbidity rate and found that the cancer-specific survival rate was increased and local recurrence was significantly reduced by neoadjuvant or adjuvant chemoradiotherapy. Domests et al. ${ }^{19}$ found a 30day mortality rate of 3.6\%, 3-year disease-free survival rate of $52.2 \%$ and 3 -year overall survival rate of $75.1 \%$. In our study, the 30-day mortality rate was $5.8 \%, 1$ - and 2-year overall survival rates were $74 \%$ and $26.4 \%$, respectively. Our 1- and 2-year disease-free survival rates were $67.3 \%$ and $40.4 \%$, respectively. We think that the reason for the lower survival time in our study is due to the inclusion of only patients who developed recurrences, the short followup period and small number of patients.

In the literature, many factors such as positive surgical margin, neoadjuvant therapy, number of metastatic lymph nodes, lymphovascular invasion and perineural invasion have been identified to be effective in determining survival after pelvic exenteration, and among these, R0 resection has been shown to be the most important prognostic factor. ${ }^{19,20,21,22,23}$ However, in their study, Kakuda et al. ${ }^{24}$ found no difference between patients who underwent R1 resection and those who underwent $\mathrm{R} 0$ resection in terms of overall survival rates (23-18 months $\mathrm{p}=0.67$ ). In our study, the radial surgical margin was positive in two patients and the effect of surgical margin positivity on survival could not be demonstrated ( $p>0.05)$. While the effect of lymph node positivity on survival has been demonstrated in many studies $22,23,24,25$, the effect of lymph node positivity on survival could not be demonstrated in the present study. We think that the reason for this is our small number of patients and short follow-up time. In our study, the factors affecting survival rates were found to be the time from the initial operation to pelvic recurrence, lymphovascular invasion, perineural invasion and neoadjuvant therapy $(\mathrm{p}=0.001$, $\mathrm{p}=0.038, \mathrm{p}=0.022, \mathrm{p}=0.045$ ).

In patients undergoing pelvic exenteration, a second surgery may be required for reasons such as adhesion due to primary surgery and fibrosis due to radiotherapy, resulting in the prolongation of the operative time, increase in postoperative complications and prolonged length of hospital stay. In a systemic review including 23 studies, the researchers found the complication rates after pelvic exenteration as 37\%$100 \% .{ }^{26}$ In our study, the complication rate was $41.1 \%$, and most of these patients developed wound infection. Reoperation was performed on one patient for postoperative bleeding and in one patient for ileal conduit leak. In the literature, there are prolonged operative times. ${ }^{20}$ In our study, the mean operative time was recorded as $200.88 \pm 9.27$ min. We think that the operative time in this study is shorter than those reported in the literature because all the surgical interventions were performed by the same team of experienced professionals.

Radiological studies are unable to determine whether invasion to the genitourinary organs is due to inflammation or tumour invasion in $20 \%-56 \%$ of patients undergoing pelvic exenteration..$^{27,28}$ In our series, $29.4 \%$ of the patients did not show tumour invasion to the genitourinary organs.

Although pelvic exenteration provides a high level of local control in recurrent rectal cancers, the rate of recurrence after pelvic exenteration ranges from $4.8 \%-61 \%$ (average $22 \%$ ) in the literature. ${ }^{26}$ In our study, three of all patients developed local recurrence (11.7\%), which is consistent with the literature. 


\section{Conclusion}

In conclusion, it was found that pelvic exenteration had a positive effect on survival and local recurrence in recurrent rectal cancer, and that neoadjuvant therapy increased survival rates.

\section{Ethics}

Ethics Committee Approval: University of Health Sciences Turkey, approval was obtained from the Ethics Committee of Ankara Dr. Abdurrahman Yurtaslan Oncology Health Application and Research Center (decision no: 95, date: 27.05.2020).

Informed Consent: Obtained.

Peer-review: Externally and internally peer reviewed.

\section{Authorship Contributions}

Concept: S.C., C.Y., M.O.K., F.G., E.G., B.A., L.D., Design: S.C., C.Y., M.O.K., F.G., E.G., B.A., L.D., Data Collection or Processing: S.C., C.Y., M.O.K., F.G., E.G., B.A., L.D., Analysis or Interpretation: S.C., C.Y., M.O.K., F.G., E.G., B.A., L.D., Literature Search: S.C., C.Y., M.O.K., F.G., E.G., B.A., L.D., Writing: S.C., C.Y., M.O.K., F.G., E.G., B.A., L.D.

Conflict of Interest: No conflict of interest was declared by the authors.

Financial Disclosure: The authors declared that this study received no financial support.

\section{References}

1. Canadian Cancer Society/NationalCancer Institute of Canada. Canadian Cancer Statistics 2009, Toronto, Canada, 2009. Available from: https:// www.cancer.ca/en/cancer-information/cancer-101/canadian-cancerstatistics-publication/past-editions-canadian-cancer-statistics/ / media/98DB59DCE6EE45ADABFE978EC3DBD4AD.ashx

2. NationalCancer Information Center. Cancerinformation service [Internet]. Goyang (KR): NationalCancer Information Center; c2011 [cited 2012 Jun 5]. Availablefrom: http://www.cancer. go.kr/ncic/cics_f/01/014/index. html.

3. O'Connell JB, Maggard MA, Liu JH, Liu JH, Etzioni DA, Ko CY. Are survival rates different for young and older patients with rectal cancer? Dis Colon Rectum 2004:47:2064-2069.

4. Bakx R, Visser O, Josso J, Meijer S, Slors JF, vanLanschot JJ. Man ᄀagement of recurrentrectalcancer: a populationbasedstudy in greater Amsterdam. World J Gastroenterol 2008;14:6018-6023.

5. Sebag-Montefiore D, Stephens RJ, Steele R, Monson J, Grieve R, Khanna S, Quirke P, Couture J, de Metz C, Myint AS, Bessell E, Griffiths G, Thompson LC, Parmar M. Preoperative radiotherapy versus selective post $\neg$ operative chemoradiotherapy in patients with rectal cancer (MRC CR07 and NCICCTG C016): a multicentre, randomisedtrial. Lancet 2009;373:811-820.

6. Pilipshen SJ, Heilweil M, Quan SH, Sternberg SS, Enker WE. Patıterns of pelvic recurrence following definitive resections of rectal cancer. Cancer 1984:53:1354-1362.

7. McDermott FT, Hughes ES, Pihl E, Johnson WR, Price AB. Local recurrence after potentially curative resection forrectal cancer in a series of 1008 patients. Br J Surg 1985;72:34-37.
8. Ito Y, Ohtsu A, Ishikura S, Boku N, Nihei K, Ogino T, Ikeda H. Effi-cacy of chemoradiotherapy on painrelief in patients with intraᄀpelvic recurrence of rectal cancer. Jpn J Clin Oncol 2003;33:180-185.

9. Brunschwig A. Complete excision of pelvicviscera for advancedc arcinoma. Cancer 1948;1:177-183.

10. Boey J, Wong J, Ong GB. Pelvic exenteration for locally advanced colorectal carcinoma. Ann Surg 1982;195:513-518.

11. Lopez MJ, Kraybill WG, Downey RS, Johnston WD, Bricker EM. Exenterative surgery for locally advanced rectosigmoid cancers. Is it worthwhile? Surgery 1987;102:644-651.

12. Jimenez RE, Shoup M, Cohen AM, Paty PB, Guillem J, Wong WD. Contemporary outcomes of total pelvic exenteration in treatment of colorectal cancer. Dis Colon Rectum 2003;46:1619-1625.

13. Law WL, Chu KW, Choi HK. Total pelvic exenteration for locally advanced rectal cancer. J Am Coll Surg 2000;190:78-83.

14. Palmer G, Martling A, Cedermark B, Holm T. A population-based study on the management and outcome in patients with locally recurrent rectal cancer. Ann Surg Oncol 2007;14:447-454.

15. Pawlik TM, Skibber JM, Rodriguez-Bigas MA. Pelvic exentera-tion for advanced pelvic malignancies. Ann Surg Oncol 2006;13:612-623.

16. Mirnezami AH, Sagar PM, Kavanagh D, Witherspoon P, Lee P, Winter D. Clinical algorithms for the surgical management of lo-cally recurrent rectal cancer. Dis Colon Rectum 2010;53:1248-1257.

17. Moriya Y, Akasu T, Fujita S, Yamamoto S. Total pelvic exenteration with distal sacrectomy for fixed recurrent rectal cancer inthe pelᄀvis. Dis Colon Rectum. 2004:47:2047-2053.

18. Heriot AG, Tekkis PP, Darzi A, Mackay J. Surgery for local recurrence of rectal cancer. Colorectal Dis 2006;8:733-747.

19. Domests, Colquhoun Ph, Taylor B, Izawa JI, House AA, Luke PPW. Total pelvic exenteration for rectal cancer: out come sand prognostic factors. Can J Surg 2011;54:387-393.

20. Ferenschild FT, Vermaas M, Verhoef C, Ansink AC, Kirkels WJ, Eggermont AMM, de Wilt JHW. Total pelvic exenteration for primary and recurrent malignancies. World J Surg 2009;33:1502-1508.

21. Hsu TW, Chiang FF, Chen MC, Wang HM. Pelvic exenteration for men with locally advanced rectal cancer: a morbidity analysis of complicated cases. Asian J Surg 2011;34:115-120.

22. Bernstein TE, Endreseth BH, Romundstad P, Wibe A; Norwegian Colorectal Cancer Group. Circumferential resection margin as a prognostic factor in rectal cancer. Br J Surg 2009;96:1348-1357.

23. Kelly ME, Winter DC; Pelv Ex Collaborative. Surgical and survival outcomes following pelvic exenteration for locally advanced primary rectal cancer: results from an international collaboration. Ann Surg 2019;269: 315-321.

24. Kakuda JT, Lamont JP, Chu DZ, Paz IB. The role of pelvic exenteration in the management of recurrent rectal cancer. Am J Surg 2003;186:660-664.

25. Ishiguro S, Akasu T, Fujita S, Yamamoto S, Kusters M, Moriya Y. Pelvic exenteration for clinical T4 rectal cancer: oncologic outcome in 93 patients at a single institution over a 30-year period. Surgery 2009;145:189-195.

26. Yang T, Morris D, Chua T. Pelvic exenteration for rectal cancer: a systematic review. Dis Colon Rectum 2013;56:519-531.

27. Hida J, Yasutomi M, Maruyama T, Akihiro Nakajima M.D., Uchida T, Wakano T, Tokoro T, Fujimoto K. Results from pelvic exenteration for locally advanced colorectal cancer with lymphnode metastases. Dis Colon Rectum 1998;41:165-168.

28. Lehnert T, Methner M, Pollok A, Schaible A, Hinz U, Herfarth C. Multivisceral resection for locally advanced primary colon and rectal cancer: an analysis of prognostic factors in 201 patients. Ann Surg 2002;235:217-225 